\title{
1 Tasman Sea biological response to dust storm events during the austral 2 spring of 2009.
}

$4 \quad$ A.J.Gabric ${ }^{1}$, R.Cropp ${ }^{1}$, G.McTainsh ${ }^{1}$, H.Butler ${ }^{2}$, B.Johnston ${ }^{3}$, T.O'Loingsigh $^{1}$ and Dien Van Tran ${ }^{1}$

$5 \quad{ }^{1}$ School of Environment, Griffith University, Nathan, Qld, 4111.

$6 \quad{ }^{2}$ School of Agricultural, Computational \& Environmental Sciences, University of Southern

7 Queensland, Toowoomba, Qld, 4350

$8 \quad{ }^{3}$ School of Natural Science, Griffith University, Nathan, Qld, 4111.

10 Abstract

During the austral spring of 2009 several significant dust storms occurred in SE Australia including the so-called 'Red Dawn' event in late September. Estimates of $2.5 \mathrm{Mt}$ total suspended particulate sediment lost off the Australian coast in the $3000 \mathrm{~km}$ long dust plume, make it the largest offcontinent loss of soil ever reported. Much of this material was transported over the coastline of New South Wales and into the adjacent Tasman Sea. Long term model simulations of dust deposition over the southwest Tasman Sea suggest the amount deposited during the spring of 2009 was about three-times the long term monthly average. Previous satellite-based analyses of the biological response of Tasman Sea waters to dust-derived nutrients are equivocal or have observed no response. Satellite-derived surface chlorophyll concentrations in the southern Tasman during the spring of 2009 are well above the climatological mean, with positive anomalies as high as $0.5 \mathrm{mg} \mathrm{m}^{-3}$. Dust transport simulations indicate strong deposition to the ocean surface, which during both the 'Red Dawn' event and mid-October 2009 dust storm events was enhanced by heavy precipitation. Cloud processing of the dust aerosol may have enhanced iron bioavailability for phytoplankton uptake. 
Aeolian deposition of nutrient-rich dust has been shown to stimulate phytoplankton growth in various oligotrophic oceanic regions of the Northern Hemisphere (Bishop et al. 2002; Harrison et al. 1999; Lenes et al. 2001). Although the evidence is limited, event-based analyses in waters proximal to the Australian continent have shown similar phytoplankton responses to dust deposition in the Southern Ocean south of Australia (Gabric et al. 2010), and in subtropical waters off southern Queensland (Shaw et al. 2008). However, other event-based studies have found little or no phytoplankton response to even major dust storm events in Australian waters (Mackie et al. 2008). Taking a climatological approach, Cropp et al. (2013) analysed a 20-year record of air parcel trajectories from the Lake Eyre Basin (LEB) in central Australia, and argued that marine biological receptivity to dust-derived nutrients is seasonally variable, and often not in synchrony with the timing of dust deposition. Cropp et al. (2013) suggest this may explain why some large dust storm events have not always produced a clear phytoplankton response in ocean waters adjacent to the continent.

Dust storm frequency in Australia is strongly seasonal and related to wind conditions, rainfall, and vegetation patterns, with peak dust storm activity in northern Australia occurring during spring and early summer, and activity in southern Australia reaching a maximum during summer (McTainsh and Leys 1993). Dust from Australian continental sources such as the LEB is entrained by warm prefrontal northerly winds, frontal westerlies and post-frontal southerlies (Strong et al. 2010) and transported either to the north-west over the Indian Ocean, south over the Southern Ocean, or southeast over the Tasman Sea in association with the west-to-east passage of cold fronts (McTainsh 1998). During the austral spring and summer, the northerly migration of the band of cold fronts contributes to increased dust storm activity over south-eastern Australia (McTainsh, 1998) and increases the likelihood of dust deposition over the adjacent oceans. Dust deposition events in the Subantarctic Southern Ocean have resulted in strong phytoplankton growth (Gabric et al. 2010), however, analyses of dust deposition over the Tasman Sea have not revealed a similar phytoplankton response (Mackie et al. 2008).

An anomalously intense dust storm event on 22 and 23 September 2009, called "Red Dawn" by the media, most likely originated in the southern LEB, the Strzelecki sub-basin and western and central New South Wales (NSW) and was the largest to pass over Sydney, Australia (as measured by its effect on visibility) since records began in 1940. Estimates of $2.54 \mathrm{Mt}$ total suspended particulate sediment lost off the Australian coast in the $3000 \mathrm{~km}$ long dust plume, make it the largest offcontinent loss of soil ever reported (Leys et al. 2011). The vertical distribution of dust from lidar 
satellite data and analysis of model results also indicate that significant amounts of dust aerosols were transported over the Tasman Sea toward New Zealand (Choobari et al. 2012). Mineralogical analyses of the Red Dawn event showed the dust's elemental composition included high amounts of Si $(24 \%)$ and $\mathrm{Fe}(6 \%)$, with $50 \%$ of the particles in the $<10 \mu \mathrm{m}$ particle size range, indicating longrange transport from source (Aryal et al. 2012).

Presented here is a detailed analysis of the marine biological response in the Tasman Sea from 25$40^{\circ} \mathrm{S}$ during September-October, 2009. The impact of dust deposition to the ocean surface is evaluated using satellite-derived estimates of phytoplankton biomass, as indicated by surface chlorophyll (CHL), and atmospheric aerosol burden, indicated by aerosol optical depth (AOD). To examine the impact on the Tasman Sea, we have simulated contemporaneous atmospheric dust load and deposition over the Tasman using a regional dust transport model that provides daily data for the study period.

\section{Materials and Methods}

\section{Study Region Characteristics}

Lying between the Coral Sea and the Southern Ocean, the Tasman Sea (Fig. 1) spans the latitudes $30-50^{\circ} \mathrm{S}$, extending over $2800 \mathrm{~km}$ north-south, and includes sub-tropical to Subantarctic water masses (Anon. 1953). The main geostrophic feature along the eastern continental shelf is the East Australian Current (EAC), which flows southward until near $32^{\circ} \mathrm{S}$ where it detaches from the coast (Godfrey et al. 1980; Ridgway and Dunn 2003). The EAC then veers east between $32^{\circ} \mathrm{S}$ and $34^{\circ} \mathrm{S}$ to form the Tasman Front, where it flows across the Tasman Sea (Suthers et al. 2011). The hydrodynamic situation south of the Tasman Front is complex with a large number of mesoscale eddies, some semi-permanent features, originating within the EAC, and termed the 'Eddy Avenue' (Everett et al. 2012), that can significantly affect the local phytoplankton biomass (Everett et al. 2012; Suthers et al. 2011). Cyclonic (upwelling) eddies within this eddy field have almost double the $\mathrm{CHL}\left(0.35 \mathrm{mg} \mathrm{m}^{-3}\right)$ of anticyclonic eddies $\left(0.18 \mathrm{mg} \mathrm{m}^{-3}\right.$ ) (Everett et al. 2012). Observations from a long-term ocean station off eastern Tasmania show that the southward penetration of the EAC has increased over the past 60 years (Ridgway 2007).

Spanning such a large meridional area, the Tasman Sea is characterised by high spatial heterogeneity in biological activity. Macro-nutrients are low in the northern sub-tropical region (Ellwood et al. 2013), but high in the southern Tasman (Bowie et al. 2011). Longhurst (2007) states that the 
southern Tasman (east of Tasmania) exhibits a typical spring bloom with CHL maximal in late September or early October. However, interannual variability in $\mathrm{CHL}$ is high with the bloom onset varying by as much as four months at a fixed location. Satellite-derived climatologies of CHL in the northern Tasman Sea show a peak in winter (May-October), decreasing to low levels from November to April. In March, high CHL is concentrated in the Subtropical Convergence zone near $40^{\circ} \mathrm{S}$ (Hayes et al. 2005).

Silicate concentrations along the east coast of the Australian continent are low (typically $<2 \mu \mathrm{M}$ ) and have declined in recent decades (Condie and Dunn 2006; Thompson et al. 2009), possibly due to a change in the long-term supply from southward-flowing EAC water (Ridgway 2007). The role of Fe in mediating macro-nutrient uptake in phytoplankton is well documented with growth rates low in Fedepleted regions (de Baar et al. 1999; Timmermans et al. 2004). Given the significant decline in surface silicate over the period 1947-2004, both Fe and silicate co-limitation may affect phytoplankton growth in the Tasman Sea, and the occasional deposition of Fe and silicate-rich dust may promote diatoms blooms. In a meridional transect from $33-43^{\circ} \mathrm{S}$ during summer, Hassler et al. (2014) note that cyanobacteria dominate in subtropical waters of the northern Tasman Sea, with non-diazotroph phytoplankton nitrogen limited. This contrasted with the subantarctic water mass in the southern Tasman Sea, where the phytoplankton community was dominated by a bloom of haptophytes. The low productivity in the subantarctic zone was explained by light limitation, but nitrogen, silicic acid, as well as Fe, were all depleted to the extent that they could become colimiting. We note that Trichodesmium spp., dinitrogen-fixing cyanobacteria, often form extensive blooms in subtropical ocean waters off north-eastern Australia (Carpenter et al. 1992). However, of relevance here, is that Trichodesmium, unlike other phytoplankton, are able to mediate dust dissolution, most likely via reduction(Rubin et al. 2011). Several field studies document the ability of Trichodesmium to utilize Fe by accelerating the rate of Fe dissolution from oxides and dust, through as yet unspecified cell-surface processes (Rubin et al. 2011; Shaked and Lis 2012).

Analysis of ocean colour data reveals that the Tasman Sea contains the largest non-coastal surface $\mathrm{CHL}$ concentrations within the South Pacific Ocean, with the variability in phytoplankton concentrations linked to mesoscale eddies (Tilburg et al. 2002). Upwelling and downwelling associated with these eddies can increase vertical mixing and nutrient concentrations in the upper ocean. Generally, high-phytoplankton concentrations are confined either to cold-core cyclonic eddies or along the coast, where upwelling can transport nutrients into the euphotic zone and stimulate phytoplankton growth (Suthers et al. 2011). High resolution eddy-resolving modelling suggests enhanced eddy activity with climate change may increase the nutrient supply to the upper 
ocean and cause an increase in the phytoplankton concentrations and primary productivity by $10 \%$ in the western Tasman Sea (Matear et al. 2013).

127 Long-term measurements at an inshore location, Port Hacking (similar to $34^{\circ} \mathrm{S}$ ), show a 128 phytoplankton community that is dominated by diatoms during spring and with maximal CHL between August-October (Thompson et al. 2009). SeaWiFS CHL anomalies show substantial 130 ( $+100 \%$ of monthly mean) episodic blooms occur at Port Hacking, with notable events in August 1998, October 2002 and January 2007. Although these are not convincingly explained, there is some evidence that dust-derived nutrients are a causative factor in the increased frequency of coastal phytoplankton blooms in NSW (Ajani et al. 2011).

Based on analysis of dust storm seasonality and aeolian transport from the continent, the likelihood of dust deposition over the Tasman Sea is relatively low from January through August, moderate during early spring, September-October, and low from November-December (Cropp et al. 2013). However, Cropp et al. (2013) found that ocean biological receptivity (as measured by mixed layer $\mathrm{CHL}$ and irradiance) to an injection of atmospheric nutrients is low during spring, so that a bloom is unlikely to develop at this time. This is consistent with analysis of a dust storm that passed over the southern Tasman during October 2003 and that produced no discernible phytoplankton response 7 to 30 days after the dust storm (Boyd et al. 2004; Mackie et al. 2008).

A dust storm during early February 2005 coincided with sampling in the northern Tasman (in the vicinity of the Tasman Front) and although there was an increase in mixed layer (ML) iron (Fe) concentrations, no increase in primary production post-dust deposition was observed (Ellwood et al. 2013). Field data collected in the north-eastern Tasman $\left(\sim 29^{\circ} \mathrm{S}, 170^{\circ} \mathrm{E}\right)$ in March-April, 2006 during and after a cyclone, showed elevated surface ocean inventories of Fe, suggestive of a dust source, which was probably enhanced by anomalously high wet deposition (Law et al. 2011). Shipboard dust-addition experiments showed that diazatrophic nitrogen fixation increased by an order of magnitude (Law et al. 2011). The observed ten-fold increase in nitrogen fixation in situ exceeded that reported in other nutrient perturbation experiments despite comparatively low concentrations of in situ dissolved $\mathrm{Fe}$, indicating that Fe bioavailability may be a critical factor in determining the phytoplankton response to dust-derived nutrients in the Tasman Sea.

The bioavailability of $\mathrm{Fe}$ in the ocean requires it to be in a soluble form as one precondition, and $\mathrm{Fe}$ in mineral dust is typically insoluble (Mackie et al. 2008). However, the factors affecting $\mathrm{Fe}$ dissolution are multiple and complex, and include its different possible phases (particulate, colloidal, soluble), and the presence of Fe-binding ligands, which may lead to a redefinition of the term 
'dissolved iron' (Breitbarth et al. 2010). Jickells and Spokes (2001) report that overall solubility of aerosol Fe at seawater $\mathrm{pH}$ is $\mathbf{0 . 8}-\mathbf{2 . 1 \%}$ of the total Fe deposited, however, wet-deposited mineral aerosols had a much higher soluble Fe (14\%) than dry deposited. The influence of aerosol cloud processing on enhancing Fe solubility has been noted in several studies (Shi et al. 2009; Shi et al. 2012; Zhang et al. 2013).

\section{Dust event observations}

The reduction in atmospheric visibility during a dust storm, or other dust entrainment event, is referred to as dust visibility reduction (DVR), and this can be used as a quantitative measure of the intensity of an event (Gabric et al. 2010). DVR is computed as follows:

$\mathrm{DVR}=\mathrm{V}_{\max }-\mathrm{V}_{\text {rec }}$,

where, $V_{\max }$ is the upper limit of measured visibility $(50 \mathrm{~km})$ as used by Australian Bureau of Meteorology ( $A B M$ ) observers, and $V_{\text {rec }}$ is the recorded visibility associated with the dust event. DVR provides a numerical value for dust entrainment event intensity (from 0 to $50 \mathrm{~km}$ ) without the need to classify events into different types. The DVR data is presented as a cumulative total of those observer stations recording an event (rather than an average across stations) because, in our opinion this is a better way of illustrating the combined effects of the frequency and intensity of dust entrainment events. High cumulative DVR values, therefore, indicate that many ABM stations were recording dust and that most of these stations recorded severe dust conditions. DVR data was gathered from a total of 138 observing stations which included those in Queensland south of latitude 23.3 degrees (Rockhampton), and all stations in NSW.

\section{Dust transport and deposition model}

The connection between individual dust storm events in southern Australia and resultant deposition over the adjacent ocean was investigated using the integrated wind erosion and dust transport model (CEMSYS) to simulate the daily deposition during Sept-Dec 2009. The CEMSYS model has been used for modelling several dust storms in Australia (Lu and Shao 2001; Shao and Leslie 1997) and was successfully validated using concurrent dust concentration data for a major dust storm event that moved north-east over the continent during October 2002 (McTainsh et al. 2005; Shao et al. 2007). CEMSYS is a process-based model which couples an atmospheric sub-model, a wind erosion sub-model, and a dust transport and deposition sub-model. These sub-models are supported by a GIS database. The structure and details of the various sub-models is outlined in Shao and Leslie 
187 (1997) and Lu and Shao (2001). CEMSYS takes into account the atmospheric conditions (wind speed, rainfall and temperature), soil conditions (soil texture and soil water) and surface vegetation. For this study, CEMSYS was run at $0.45^{\circ} \times 0.45^{\circ}$ resolution over the domain $108^{\circ} \mathrm{E}-168.75^{\circ} \mathrm{E}, 8.1^{\circ} \mathrm{S}-$ $57.6^{\circ} \mathrm{S}$, which covers the Australian continent, Southern Ocean and Tasman Sea for the simulation period. Atmospheric conditions used in the CEMSYS simulations for each day in the simulation period were obtained from HIRES, a High Resolution limited area atmospheric prediction model developed by Leslie (1998). Land surface information required for the CEMSYS simulations is summarised in Table 1. It was assumed that vegetation cover was slowly varying and therefore constant for each month in the simulation. Vegetation cover for each month was estimated based on each month's Leaf Area Index (LAI) calculated from MODIS NDVI data using the empirical relationships developed by McVicar et al. (1996b). Soil texture across the continent was divided up into USDA soil texture classes. Each soil class was characterised by a particle-size density function. The particle-size distributions of each soil class were considered to be unchanged during wind erosion events. Soil moisture varied considerably during the simulation period and was modelled accordingly within CEMSYS (Shao et al. 2007).

\section{Satellite Data}

203

204

\section{Results and Discussion}

The Tasman Sea sub-region selected for the satellite data analysis covers $25-40^{\circ} \mathrm{S}$ and $150-170^{\circ} \mathrm{E}$ and includes the area under the path of the Red Dawn dust plume. Strictly, the northern extent of our study region extends into the Coral Sea as the Tasman's northern boundary is defined as $30^{\circ} \mathrm{S}$ (Anon. 1953). Daily and 8-day MODIS (Aqua) binned CHL and AOD data at 550-nm and 4-km resolution are retrieved for the period September-December 2009. The study region is divided into five-degree latitude bands for statistical analysis. Climatological mean $\mathrm{CHL}$ is derived from the available MODIS 8-day archive (2002-2013) and anomalies are computed from this mean. Rainfall rate data at a resolution of $0.25^{\circ}$ latitude-longitude are obtained from the Special Sensor Microwave/Imager (SSM/I) archive maintained by Remote Sensing Systems and sponsored by the NASA Earth Science MEaSUREs Program (www.remss.com).

\section{Synoptic Meteorology and Dust Deposition}

Fig. 2a shows the synoptic mean sea level barometric pressure charts just before and during the 'Red Dawn' dust storm event from 22-25 September 2009 (days of the year 265-268). On 22 and 23 
September 2009, a broad area of low pressure dominated south-eastern Australia, while a cold front stretched from $28-37^{\circ} \mathrm{S}$ and a large low pressure trough stretched from $12-35^{\circ} \mathrm{S}$. With the passage of the trough and the cold front from west to east, wind direction over the LEB and western NSW changed from north or north-westerly to south-west and westerly (Leys et al. 2011). During and prior to the 'Red Dawn' event, winds recorded in the western part of NSW were between 80 and 100 $\mathrm{km} / \mathrm{h}$ and elevated dust was recorded at numerous Dustwatch stations across NSW on 22 and 23 September (http://www.environment.nsw.gov.au/resources/dustwatch/DWNL090928.pdf).

MODIS Terra pseudo-true colour imagery captured for September 22-23 (Fig. 3a) show the passage and extent of the dust plume as it crosses the coast and moves north-east over the Tasman Sea. The dust is clearly entrained in north-westerly winds associated with a cyclonic system to the south (Fig. 3b). On 25 September a subsequent cold front passed over the same region. Of relevance to the subsequent pattern of dust deposition over the Tasman Sea, is the intense cyclonic system centred at approximately at $40^{\circ} \mathrm{S}, 165^{\circ} \mathrm{E}$ on 23 and 24 of September (Fig. 2).

The sum of the DVR values during September-October 2009 from all observing stations which recorded a dust event (including multiple daily DVR records when they occurred) is shown in Fig. 4a. Of the 61 days in September and October 2009, 40 days (or 65.5\%) were dusty somewhere in the defined monitoring region. The most active day was September 23 when 107 (or $77.5 \%$ ) of 138 stations recorded dust. The 'Red Dawn' event was followed by two smaller events in late September/early October, plus another dust storm (61 stations involved) in mid-October as shown in the DVR time series for the September-October period (Fig. 4a).

The Hovmoller plot of the CEMSYS simulated dust deposition (Fig. 5b-c) shows strong deposition between $25-35^{\circ}$ S (Fig. 5b-d) on day 266 (Sept 23), following the 'Red Dawn' dust storm on day 265, and also further south $\left(30-40^{\circ} \mathrm{S}\right)$ on day 268 (Sept 25$)$. This confirms that the dust plume transport was driven by the cyclonic low pressure system which was centred on the Tasman Sea between 35$40^{\circ} \mathrm{S}$ on the 23 September (Fig. 2), transported north to south and then likely rained out. Another strong dust deposition event is simulated on days 286-287 (October 13-14) with dust again deposited over a large latitude band, especially east of $155^{\circ} \mathrm{E}$ (Fig. 5b-d).

Fig. 6a-b show the 3-day average rainfall rate for 22-24 Sept and 13-15 October from the SSM/I sensor, and confirms widespread precipitation over the Tasman Sea on both occasions. Fig. 6c-d show the CEMSYS simulated proportion of wet deposition for these two periods, confirming that extensive wet deposition occurred over the southern Tasman, particularly during the September event. As noted above, cloud processing of the dust aerosol followed by wet deposition likely 
enhanced the deposition rates and the solubility of dust-derived Fe deposited to the ocean during these events.

252

253

254

255

256

257

258

259

260

261

262

263

264

265

266

267

268

269

270

271

272

273

274

275

276

277

278

279

280

\section{Satellite $A O D$ and $C H L$}

The MODIS AOD daily time series (Fig. 4b) shows a strong spike from 22-24 September, which is remarkable as the AOD values were averaged over the entire Tasman study region. The MODIS 3-day average AOD (Fig. 4c) confirms the extensive impact of the dust plume on AOD and atmospheric aerosol burden.

To illustrate the meridional change in bloom phenology in the Tasman, the climatological mean monthly CHL derived from the MODIS archive is presented in five-degree latitude bands in Fig. 7 . The $\mathrm{CHL}$ peak occurs later in the year with increasing latitude; the timing of peak $\mathrm{CHL}$ ranging from August in subtropical waters to December, south of $40^{\circ} \mathrm{S}$. The magnitude of the seasonal $\mathrm{CHL}$ peak also increases markedly with latitude, from $0.23 \mathrm{mg} \mathrm{m}^{-3}$ in subtropical waters to $0.47 \mathrm{mg} \mathrm{m}^{-3}$ in the subantarctic zone.

Hovmoller latitude-time plots of MODIS 8-day CHL concentrations and climatology (Fig. 8a-b) show that the phytoplankton response seems to be largely confined to the south of the Tasman Front, at approximately $32^{\circ} \mathrm{S}$ (Fig. 8c, 9c), with the greatest positive anomalies $\left(>0.6 \mathrm{mg} \mathrm{m}^{-3}\right.$ ) occurring south of $35^{\circ} \mathrm{S}$ between days 270-280, even though deposition was simulated further north (Fig. 5). Assuming that dust-derived Fe stimulated the phytoplankton response, this is consistent with the observations of Ellwood et al. (2013) who suggested that Fe was unlikely to limit primary production north of the Tasman Front. Alternatively, it may also suggest that the dust-derived Fe deposited in the northern Tasman was less soluble and therefore less available for phytoplankton.

\section{Baseline Dust Inputs to the Tasman Sea}

Fig. 10 shows the annual dust deposition $\left(\mathrm{g} \mathrm{m}^{-2} \mathrm{yr}^{-1}\right)$ from a previous CEMSYS model simulation for the period $2001-2011$ in the region $30-45^{\circ} \mathrm{S}, 145-154^{\circ} \mathrm{E}$ (shown as shaded in the map insert), which includes the southwest Tasman Sea and subantarctic waters to the south. Although this area excludes the northern and eastern Tasman, which were affected by dust from the Red Dawn event, the seasonality and episodic nature of dust storm events is clear, with 2009 the fourth highest annual deposition in the time series. The mean dust deposited over the southwest Tasman during the spring of 2009 was $0.17 \mathrm{Mt}$ per month, which is almost three times the long-term average monthly dust deposition of $0.063 \pm 0.10 \mathrm{Mt}$ and underscores the intensity of the 2009 dust storm season. 
It is interesting to estimate the amount of dust-derived Fe that was delivered to the Tasman surface waters during the Red Dawn event. Table 2 gives the CEMSYS modelled dust deposition for 22-25 September 2009 , in ten $3^{\circ} \times 3^{\circ}$ cells that cover most of the Tasman Sea. There are clear spatial gradients in deposition with higher values near the Australian coast, and in the northern Tasman. The east-west spatial gradient in modelled deposition is broadly consistent with the satellite data on $A O D$ given in Figure $4 c$, bearing in mind that the relationship between dust loading, satellite AOD and dust deposition is complex. Assuming a mean depositional flux of $1 \times 10^{-8} \mathrm{~g} \mathrm{~m}^{-2} \mathrm{~s}^{-1}$ and an Fe content of 3.5\% for Australian dust (Mackie et al. 2005), this equates to a flux of $3.5 \times 10^{-10} \mathrm{~g} \mathrm{~m}^{-2} \mathrm{~s}^{-1}$ of particulate Fe, corresponding to a delivery of $0.12 \mathrm{mg} \mathrm{Fe} \mathrm{m}^{-2}$ over the four-day Red Dawn period. By way of comparison, Jickells et al. (2005) use the results from three modelling studies to derive a composite estimate of annual dust deposition over the Tasman Sea in range $0.2-1 \mathrm{~g} \mathrm{~m}^{-2} \mathrm{yr}^{-1} \cong 0.6-$ $\left.3 \times 10^{-8} \mathrm{~g} \mathrm{~m}^{-2} \mathrm{~s}^{-1}\right)$. It is also interesting to note that the deposition flux over the Tasman during the Red Dawn event was a factor of five higher than that modelled over the Subantarctic Southern Ocean during the very active 2002 dust storm season (Gabric et al. 2010).

The September-November period coincides with rapid shoaling of the ML in the Tasman, from $160 \mathrm{~m}$ to $40 \mathrm{~m}$ (Tilburg et al. 2002). Assuming an ocean ML depth of $100 \mathrm{~m}$ during late September, the $\mathrm{ML}$ particulate Fe concentration would be $0.0012 \mathrm{mg} \mathrm{m}^{-3}$. However, given a typical oceanic vertical mixing coefficient of $10^{-4} \mathrm{~m}^{-2} \mathrm{~s}^{-1}$ it would take approximately 12 days for a conservative tracer to be mixed uniformly over a $100 \mathrm{~m} \mathrm{ML}$, which is unlikely for particulate $\mathrm{Fe}$, given dissolution and rapid uptake by phytoplankton (Bowie et al. 2009). A more reasonable estimate of the particulate Fe concentration in the upper $10 \mathrm{~m}$ of the water column is $0.012 \mathrm{mg} \mathrm{m}^{-3}$ or $0.21 \mathrm{nmole}^{-1}$. This compares with observed surface values of particulate Fe of about $0.05-0.2$ nmole $\mathrm{L}^{-1}$ in the subantarctic zone, measured at Station P3 $\left(46^{\circ} \mathrm{S}, 153^{\circ} \mathrm{E}\right)$ during January-February 2007 (Bowie et al. 2009). Interestingly, there was quite low dust storm deposition over the SW Tasman Sea during 2007 (see Fig. 10).

Perhaps the largest uncertainty in such estimates is the solubility and bioavailability of this particulate Fe. A broad range of physical, chemical and biological factors can affect dust-derived Fe solubility in both the marine atmosphere and upper ocean (Baker and Croot 2008). Jickells and Spokes (2001) report that overall solubility of aerosol Fe at seawater $\mathrm{pH}$ for wet deposited mineral aerosols is a much higher than for dry deposited (14\% compared with about $1 \%)$, which was indeed the situation in the southern Tasman during the Red Dawn event (see Fig 6). A physical control on aerosol Fe solubility has been suggested by Baker and Jickells (2006), namely the preferential removal of larger particles during long-range transport leading to reduced modal size of the dust 
population. Such smaller dust particles have a correspondingly larger surface area to volume ratio, and hence a greater proportion of their Fe content close enough to the particle surface to dissolve. Given the source area for the dust likely being the LEB (over $1000 \mathrm{~km}$ west of Sydney), the approximate distance travelled by the dust plume to the northern Tasman was well over $2000 \mathrm{~km}$, and almost $3000 \mathrm{~km}$ for those dust particles transported first northeast across the coast, and then from north to the south by the cyclonic system centred at between $35-40^{\circ} \mathrm{S}$. The theory proposed by Baker and Jickells (2006) suggests that dust-derived Fe transported the longer distance to the southern Tasman will be more soluble and hence elicit a greater phytoplankton response. Both mechanisms affect the solubility of particulate $\mathrm{Fe}$ and could help explain the contrasting phytoplankton responses observed between the northern and southern Tasman Sea (Figs 8 and 9).

\section{Chlorophyll Anomalies}

The mid-October deposition event simulated around day 286 seems to promote a widespread, $\mathrm{CHL}$ response between days $290-295$, which is again confined to the south of $32^{\circ} \mathrm{S}$. CHL concentrations achieved during these events are well above the climatological mean values for spring, with positive anomalies as high as $0.5 \mathrm{mg} \mathrm{m}^{-3}$. As noted above, the ocean $\mathrm{ML}$ depth decreases rapidly through October, so that light would be less important in limiting of phytoplankton growth at this time.

The $\mathrm{CHL}$ anomaly Hovmoller plot by longitude shows high inshore anomalies occur throughout the spring season north of $35^{\circ} \mathrm{S}$ (Fig. 9a-b), which are likely due to eddy pumping or coastal upwelling. Figure 11 shows sea-level height anomalies (left-panel) and SST (right panel) for September 24. The penetration of warm EAC waters well south of the Tasman Front with entrainment of warm waters in an inshore eddy at $36^{\circ} \mathrm{S}$ is notable. The SST data clearly show both warm core $\left(36^{\circ} \mathrm{S}, 153^{\circ} \mathrm{E}\right)$ and cold core $\left(33^{\circ} \mathrm{S}, 156^{\circ} \mathrm{E}\right)$ eddies, which persisted for several days in the satellite record (IMOS 2009). However, the large offshore extent of positive $\mathrm{CHL}$ anomalies south of $35^{\circ} \mathrm{S}$ (Fig. 9c), strongly suggest the $\mathrm{CHL}$ increase post the Red Dawn event was due to the deposition of dust.

Fig. 12a-b show the spatial distribution of $\mathrm{CHL}$ anomalies $\left(\mathrm{mg} \mathrm{m}^{-3}\right)$ in the octad periods following the 'Red Dawn' and mid-October dust storm events. The basin-wide extent of these plumes of elevated CHL suggests that phytoplankton biomass increased over a large part of the Tasman Sea, that could not be caused by localized enhanced nutrient supply from coastal upwelling or cyclonic eddy pumping, since both processes are confined to waters in the western Tasman and closer to the NSW coast (Fig. 11). Taken together with the timing of simulated dust deposition this points to dustderived nutrients as the most likely cause. 


\section{Conclusions}

346 We have presented various data on ocean surface $\mathrm{CHL}$, atmospheric aerosol loading (from $\mathrm{AOD}$ ) and 347 atmospheric dust deposition (modelled) over the Tasman Sea to explore the connection between 348 the austral spring dust storm season of 2009, and the biogeochemical response of the adjacent 349 ocean. Continental observations of DVR and dust transport model simulations suggest the 350 deposition of dust to the Tasman Sea was significant, albeit episodic, and enhanced by widespread precipitation, during the late September and mid-October events.

The two dust storms that traversed the south-east coast of Australia during late September and midOctober 2009 appear to have caused a widespread spike in phytoplankton biomass in the Tasman Sea, especially south of the Tasman Front. Although the 'Red Dawn' event of late September was one of the largest in the record in terms of total soil loss, the biological response was almost as strong following the less intense mid-October event, suggesting the timing and mode of delivery of dust-derived nutrients and ocean state are all critical factors. Both events were accompanied by widespread precipitation over the Tasman Sea which is thought to enhance the solubility of dust associated Fe. A previous 20-year climatological analysis of dust storm trajectories suggested that an asynchrony between deposition and ocean receptivity in the Tasman Sea would make such events rare (Cropp et al. 2013), which underscores the unusual nature of the 2009 dust storm season.

Surface CHL concentrations observed during the study period are well above the climatological mean

363 for this time of the year, with positive anomalies as high as $0.5 \mathrm{mg} \mathrm{m}^{-3}$. Although we do not have observations of in situ Fe concentration during spring 2009, results from other studies suggest that

365 Fe can limit phytoplankton growth south of the Tasman Front, which is where the greatest phytoplankton response was seen. It is also clear that multiple factors, such as the mode of deposition (wet versus dry), dust solubility, and scavenging of released Fe all interact to set the seawater concentration of bioavailable Fe (Boyd and Ellwood 2010).

It is anticipated that as a result of global warming droughts will become more frequent and the number of severe dust storms in Australia may as a consequence increase (Bhattachan and D'Odorico 2014). There is some evidence that the mean aerosol loading over the continent is already changing due to enhanced dust storm activity (Mitchell et al. 2010). Although our data describe a very active dust storm season, they raise the possibility that future enhanced delivery of Australian dust to the Tasman Sea under warming may have significant impacts on regional phytoplankton dynamics and the carbon sink of these waters. 
378 The data presented in Figs $4 \mathrm{~b}$ and $4 \mathrm{c}$ in this paper were produced with the Giovanni online data 379 system, developed and maintained by the NASA GES DISC. The SSM/I data shown in Fig. 6 were 380 produced by Remote Sensing Systems (www.remss.com) and sponsored by the NASA Earth Science 381 MEaSUREs DISCOVER Project. Data was sourced from the Integrated Marine Observing System 382 (IMOS) - IMOS is supported by the Australian Government through the National Collaborative 383 Research Infrastructure Strategy and the Super Science Initiative. 


\section{References}

Ajani, P., Ingleton, T., Pritchard, T., and Armand, L. (2011) Microalgal Blooms in the Coastal Waters of New South Wales, Australia. Proceedings of the Linnean Society of New South Wales 133, 15-31.

Anon. (1953) Limits of Oceans and Seas. Monaco.

Aryal, R., Kandel, D., Acharya, D., Chong, M.N., and Beecham, S. (2012) Unusual Sydney dust storm and its mineralogical and organic characteristics. Environmental Chemistry 9(6), 537-546.

Baker, A.R., and Croot, P.L. (2008) Atmospheric and marine controls on aerosol iron solubility in seawater. Marine Chemistry doi:10.1016/j.marchem.2008.09.003.

Baker, A.R., and Jickells, T.D. (2006) Mineral particle size as a control on aerosol iron solubility. Geophysical Research Letters 33(17), L17608.

Bhattachan, A., and D'Odorico, P. (2014) Can land use intensification in the Mallee, Australia increase the supply of soluble iron to the Southern Ocean? Scientific Reports 4.

Bishop, J.K.B., Davis, R.E., and Sherman, J.T. (2002) Robotic observations of dust storm enhancement of carbon biomass in the North Pacific. Science 298(5594), 817-821.

Bowie, A.R., Griffiths, F.B., Dehairs, F., and Trull, T.W. (2011) Oceanography of the subantarctic and Polar Frontal Zones south of Australia during summer: Setting for the SAZ-Sense study. Deep-Sea Research Part li-Topical Studies in Oceanography 58(21-22), 2059-2070.

Bowie, A.R., Lannuzel, D., Remenyi, T.A., Wagener, T., Lam, P.J., Boyd, P.W., Guieu, C., Townsend, A.T., and Trull, T.W. (2009) Biogeochemical iron budgets of the Southern Ocean south of Australia: Decoupling of iron and nutrient cycles in the subantarctic zone by the summertime supply. Global Biogeochemical Cycles 23.

Boyd, P.W., and Ellwood, M.J. (2010) The biogeochemical cycle of iron in the ocean. Nature Geoscience 3(10), 675-682.

Breitbarth, E., Achterberg, E.P., Ardelan, M.V., Baker, A.R., Bucciarelli, E., Chever, F., Croot, P.L., Duggen, S., Gledhill, M., Hassellov, M., Hassler, C., Hoffmann, L.J., Hunter, K.A., Hutchins, D.A., Ingri, J., Jickells, T., Lohan, M.C., Nielsdottir, M.C., Sarthou, G., Schoemann, V., Trapp, J.M., Turner, D.R., and Ye, Y. (2010) Iron biogeochemistry across marine systems - progress from the past decade. Biogeosciences 7(3), 1075-1097. 
Choobari, O.A., Zawar-Reza, P., and Sturman, A. (2012) Atmospheric forcing of the three-dimensional distribution of dust particles over Australia: A case study. Journal of Geophysical ResearchAtmospheres 117.

430

Condie, S.A., and Dunn, J.R. (2006) Seasonal characteristics of the surface mixed layer in the Australasian region: implications for primary production regimes and biogeography. Marine and Freshwater Research 57(6), 569-590.

Cropp, R.A., Gabric, A.J., Levasseur, M., McTainsh, G.H., Bowie, A., Hassler, C., Law, C., McGowan, H., Tindale, N., and Viscarra Rossel, R. (2013) The likelihood of observing dust-stimulated phytoplankton growth in waters proximal to the Australian continent. Journal of Marine Systems 117, 43-52.

de Baar, H.J.W., de Jong, J.T.M., Nolting, R.F., Timmermans, K.R., van Leeuwe, M.A., Bathmann, U., van der Loeff, M.R., and Sildam, J. (1999) Low dissolved Fe and the absence of diatom blooms in remote Pacific waters of the Southern Ocean. Marine Chemistry 66(1-2), 1-34.

Ellwood, M.J., Law, C.S., Hall, J., Woodward, E.M.S., Strzepek, R., Kuparinen, J., Thompson, K., Pickmere, S., Sutton, P., and Boyd, P.W. (2013) Relationships between nutrient stocks and inventories and phytoplankton physiological status along an oligotrophic meridional transect in the Tasman Sea. Deep-Sea Research Part I-Oceanographic Research Papers 72, 102-120.

Everett, J.D., Baird, M.E., Oke, P.R., and Suthers, I.M. (2012) An avenue of eddies: Quantifying the biophysical properties of mesoscale eddies in the Tasman Sea. Geophysical Research Letters 39.

Gabric, A.J., Cropp, R.A., McTainsh, G.H., Johnston, B.M., Butler, H., Tilbrook, B., and Keywood, M. (2010) Australian dust storms in 2002-2003 and their impact on Southern Ocean biogeochemistry. Global Biogeochemical Cycles 24.

Godfrey, J.S., Cresswell, G.R., Golding, T.J., and Pearce, A.F. (1980) The separation of the East Australian Current. Journal of Physical Oceanography 10(3), 430-440.

Harrison, P.J., Boyd, P.W., Varela, D.E., and Takeda, S. (1999) Comparison of factors controlling phytoplankton productivity in the NE and NW subarctic Pacific gyres. Progress in Oceanography 43(2-4), 205-234.

Hassler, C.S., Ridgway, K.R., Bowie, A.R., Butler, E.C.V., Clementson, L.A., Doblin, M.A., Davies, D.M., Law, C., Ralph, P.J., van der Merwe, P., Watson, R., and Ellwood, M.J. (2014) Primary productivity induced by iron and nitrogen in the Tasman Sea: an overview of the PINTS expedition. Marine and Freshwater Research 65(6), 517-537. 
Hayes, D., Lyne, V., Condie, S., Griffiths, B., Pigot, S., and Hallegraeff, G. (2005) Collation and Analysis of Oceanographic Datasets for National Marine Bioregionalisation. A report to the Australian Government, National Oceans Office. (CSIRO Marine Research)

IMOS (2009) Integrated Marine Observing System. http://oceancurrent.imos.org.au/. Accessed 8 February 2015

Jickells, T.D., An, Z.S., Andersen, K.K., Baker, A.R., Bergametti, G., Brooks, N., Cao, J.J., Boyd, P.W., Duce, R.A., Hunter, K.A., Kawahata, H., Kubilay, N., laRoche, J., Liss, P.S., Mahowald, N., Prospero, J.M., Ridgwell, A.J., Tegen, I., and Torres, R. (2005) Global iron connections between desert dust, ocean biogeochemistry, and climate. Science 308(5718), 67-71.

Jickells, T.D., and Spokes, L. (2001) Atmospheric iron inputs to the oceans. In The biogeochemistry of iron in seawater. (Eds. DR Turner and K Hunter) pp. 85-122. (John Wiley and Sons: New York Chichester)

Law, C.S., Woodward, E.M.S., Ellwood, M.J., Marriner, A., Bury, S.J., and Safi, K.A. (2011) Response of surface nutrient inventories and nitrogen fixation to a tropical cyclone in the southwest Pacific. Limnology and Oceanography 56(4), 1372-1385.

Lenes, J.M., Darrow, B.P., Cattrall, C., Heil, C.A., Callahan, M., Vargo, G.A., Byrne, R.H., Prospero, J.M., Bates, D.E., Fanning, K.A., and Walsh, J.J. (2001) Iron fertilization and the Trichodesmium response on the West Florida shelf. Limnology and Oceanography 46(6), 1261-1277.

Leslie, L. (1998) Weather forecasting models. In Climate Prediction for Agricultural and Resource Management,. (Eds. R Munro and L Leslie) pp. 103-116. (Bureau of Resource Sciences: Canberra.)

Leys, J.F., Heidenreich, S.K., Strong, C.L., McTainsh, G.H., and Quigley, S. (2011) PM10 concentrations and mass transport during "Red Dawn" - Sydney 23 September 2009. AEOLIAN RESEARCH 3(3), 327342.

Longhurst, A.R. (2007) 'Ecological Geography of the Sea.' 2nd edn. (Academic Press: San Diego)

Lu, H., and Shao, Y.P. (2001) Toward quantitative prediction of dust storms: an integrated wind erosion modelling system and its applications. Environmental Modelling \& Software 16(3), 233-249.

Mackie, D.S., Boyd, P.W., Hunter, K.A., and McTainsh, G.H. (2005) Simulating the cloud processing of iron in Australian dust: $\mathrm{pH}$ and dust concentration. Geophysical Research Letters 32(6).

Mackie, D.S., Boyd, P.W., McTainsh, G.H., Tindale, N.W., Westberry, T.K., and Hunter, K.A. (2008) Biogeochemistry of iron in Australian dust: From eolian uplift to marine uptake. Geochemistry Geophysics Geosystems 9. 
Matear, R.J., Chamberlain, M.A., Sun, C., and Feng, M. (2013) Climate change projection of the Tasman Sea from an Eddy-resolving Ocean Model. Journal of Geophysical Research-Oceans 118(6), 2961-2976.

McTainsh, G., Chan, Y.C., McGowan, H., Leys, J., and Tews, K. (2005) The 23rd October 2002 dust storm in eastern Australia: characteristics and meteorological conditions. Atmospheric Environment 39(7), 1227-1236.

McTainsh, G.H., A.W. Lynch, E.K. Tews (1998) Climatic controls upon dust storm occurrence in eastern Australia. J. Arid Environment 39, 457-466.

McTainsh, G.H., and Leys, J.F. (1993) Wind erosion. In Land Degradation Processes in Australia. (Eds. GH McTainsh and WC Boughton). (Longman Chesire, Melbourne)

McVicar, T., Walker, J., Jupp, D., Pierce, L., Byrne, G., and Dallwitz, R. (1996a) Relating AVHRR vegetation indices to in situ measurements of leaf area index. CSIRO Division of Water Resources, Canberra.

McVicar, T.R., Walker, J., Jupp, D., Pierce, L., Byrne, G.T., and Dallwitz, R. (1996b) 'Relating AVHRR vegetation indices to in situ measurements of leaf area index.' (CSIRO Division of Water Resources)

Mitchell, R.M., Campbell, S.K., and Qin, Y. (2010) Recent increase in aerosol loading over the Australian arid zone. Atmospheric Chemistry and Physics 10(4), 1689-1699.

Raupach, M.R. (1994) Simplified Expressions for Vegetation Roughness Length and Zero-Plane Displacement as Functions of Canopy Height and Area Index. Boundary-Layer Meteorology 71(1-2), 211-216.

Ridgway, K.R. (2007) Long-term trend and decadal variability of the southward penetration of the East Australian Current. Geophysical Research Letters 34(13).

Ridgway, K.R., and Dunn, J.R. (2003) Mesoscale structure of the mean East Australian Current System and its relationship with topography. Progress in Oceanography 56(2), 189-222.

Rubin, M., Berman-Frank, I., and Shaked, Y. (2011) Dust- and mineral-iron utilization by the marine dinitrogen-fixer Trichodesmium. Nature Geoscience 4(8), 529-534.

Shaked, Y., and Lis, H. (2012) Disassembling iron availability to phytoplankton. Frontiers in Microbiology 3.

Shao, Y.P., and Leslie, L.M. (1997) Wind erosion prediction over the Australian continent. Journal of Geophysical Research-Atmospheres 102(D25), 30091-30105. 
Shao, Y.P., Leys, J.F., McTainsh, G.H., and Tews, K. (2007) Numerical simulation of the October 2002 dust event in Australia. Journal of Geophysical Research-Atmospheres 112(D8).

Shaw, E.C., Gabric, A.J., and McTainsh, G.H. (2008) Impacts of aeolian dust deposition on phytoplankton dynamics in Queensland coastal waters. Marine and Freshwater Research 59(11), 951-962.

Shi, Z.B., Krom, M.D., Bonneville, S., Baker, A.R., Jickells, T.D., and Benning, L.G. (2009) Formation of Iron Nanoparticles and Increase in Iron Reactivity in Mineral Dust during Simulated Cloud Processing. Environmental science \& technology 43(17), 6592-6596.

Shi, Z.B., Krom, M.D., Jickells, T.D., Bonneville, S., Carslaw, K.S., Mihalopoulos, N., Baker, A.R., and Benning, L.G. (2012) Impacts on iron solubility in the mineral dust by processes in the source region and the atmosphere: A review. Aeolian Research 5, 21-42.

Strong, C.L., Parsons, K., McTainsh, G.H., and Sheehan, A. (2010) Dust transporting wind systems in the lower Lake Eyre Basin, Australia AEOLIAN RESEARCH doi:10.1016/j.aeolia.2010.11.001.

Suthers, I.M., Everett, J.D., Roughan, M., Young, J.W., Oke, P.R., Condie, S.A., Hartog, J.R., Hobday, A.J., Thompson, P.A., Ridgway, K., Baird, M.E., Hassler, C.S., Brassington, G.B., Byrne, M., Holbrook, N.J., and Malcolm, H.A. (2011) The strengthening East Australian Current, its eddies and biological effects - an introduction and overview. Deep-Sea Research Part li-Topical Studies in Oceanography 58(5), 538-546.

Thompson, P.A., Baird, M.E., Ingleton, T., and Doblin, M.A. (2009) Long-term changes in temperate Australian coastal waters: implications for phytoplankton. Marine Ecology Progress Series 394, 1-19.

Tilburg, C.E., Subrahmanyam, B., and O'Brien, J.J. (2002) Ocean color variability in the Tasman Sea. Geophysical Research Letters 29(10).

Timmermans, K.R., van der Wagt, B., and de Baar, H.J.W. (2004) Growth rates, half-saturation constants, and silicate, nitrate, and phosphate depletion in relation to iron availability of four large, open-ocean diatoms from the Southern Ocean. Limnology and Oceanography 49(6), 2141-2151.

Zhang, T.R., Shi, J.H., Gao, H.W., Zhang, J., and Yao, X.H. (2013) Impact of source and atmospheric processing on Fe solubility in aerosols over the Yellow Sea, China. Atmospheric Environment 75, 249256. 
Table 1: Summary of land surface information used in the CEMSYS simulations.

Parameter

Aerodynamic Roughness

Zero-displacement height

Leaf Area Index (LAI)

Vegetation Height

Soil particle-size distribution

Soil moisture

\section{Data Source}

Constant for bare soil

Derived from vegetation height and LAl for vegetated surfaces (Raupach 1994)

Zero for bare soil

Derived from vegetation height and LAl for vegetated surfaces (McVicar et al. 1996a)

Derived from SeaWiFS NDVI data

Adapted from the Atlas of Australia Resources

Particle-size analysis of selected soil samples

Soil moisture model integrated into CEMSYS.

594

595 
596 Table 2: CEMSYS simulated mean dust depositional flux $\left(\mathrm{g} \mathrm{m}^{-2} \mathrm{~s}^{-1}\right)$ during Red Dawn event

\begin{tabular}{|l|l|l|l|l|l|}
\hline \multicolumn{1}{r|}{$\begin{array}{c}\text { Longitude } \\
\text { Latitude }\end{array}$} & $150-153^{\circ} \mathrm{E}$ & $153-156^{\circ} \mathrm{E}$ & $156-159^{\circ} \mathrm{E}$ & $159-162^{\circ} \mathrm{E}$ & $162-165^{\circ} \mathrm{E}$ \\
\hline $31-34^{\circ} \mathrm{S}^{\circ}$ & $4.7 \times 10^{-8}$ & $3.2 \times 10^{-8}$ & $1.8 \times 10^{-8}$ & $1.0 \times 10^{-8}$ & $1.0 \times 10^{-8}$ \\
\hline $34-37^{\circ} \mathrm{S}$ & $0.96 \times 10^{-8}$ & $0.61 \times 10^{-8}$ & $0.55 \times 10^{-8}$ & $0.48 \times 10^{-8}$ & $0.48 \times 10^{-8}$ \\
\hline
\end{tabular}

597

598 
600

601

Figure 1 Tasman Sea study region (EAC: East Australian Current; STF: subtropical front)

602

Figure 2

Synoptic pressure charts for Sept 22-25, 2009 (www.bom.gov.au)

603

Figure 3

True colour image of 'Red Dawn' dust plume from MODIS Terra overpass on 23 Sept

604 2009 at (a) 00:05 UTC and, (b) 23:10 UTC on the 23 September 2009

605

Figure 4

(a) Total DVR from ABM stations in Eastern Australia during September and October 606

607

608

Figure 5 2009, (b) Time series of daily areal average aerosol optical depth from MODIS (at $550 \mathrm{~nm}$ ), and (c) AOD over the Tasman Sea during 'Red Dawn' event

609

Figure 6

Hovmoller plot of CEMSYS simulated deposition $\left(\mu \mathrm{g} \mathrm{m}^{2} \mathrm{~s}^{-1}\right)$ by longitude bands

610

611

612

Figure 7

614

Figure 8

616

$617 \quad$ Figure 9

618

Figure 10

620

Figure 11

622

623 Figure 12

624

625

SSM/I F17 three-day mean rainfall rate $\left(\mathrm{mm} \mathrm{hr}^{-1}\right)$ for (a) September 23-25, 2009 and (b) October 13-15, 2009 (source: www.remss.com), and CEMSYS simulated proportion of wet deposition for (c) September 23-25, 2009 and (d) October 13-15, 2009

MODIS-derived chlorophyll climatology (2002-13) for the Tasman Sea by latitude band, averaged over $150-170^{\circ} \mathrm{E}$.

Hovmoller plot of MODIS 8-day mean CHL data and 10-year climatology, by latitude averaged over $150-170^{\circ} \mathrm{E}$.

Hovmoller plot of MODIS 8-day mean $\mathrm{CHL}$ anomalies, by longitude $\left(150-170^{\circ} \mathrm{E}\right)$ averaged over the given latitude bands.

CEMSYS modelled long-term dust deposition time series for the southwest Tasman Sea as shown in the map insert.

Satellite sea level anomalies (left panel) and 3-day SST composite (right panel) for September 24, 2009 (from the IMOS, 2009 archive).

MODIS 8-day CHL anomalies ( $\mathrm{mg} \mathrm{m}^{-3}$ ) for (a) $30 \mathrm{Sep}-7 \mathrm{Oct}$, 2009, and (b) 16-23 Oct, 2009. 


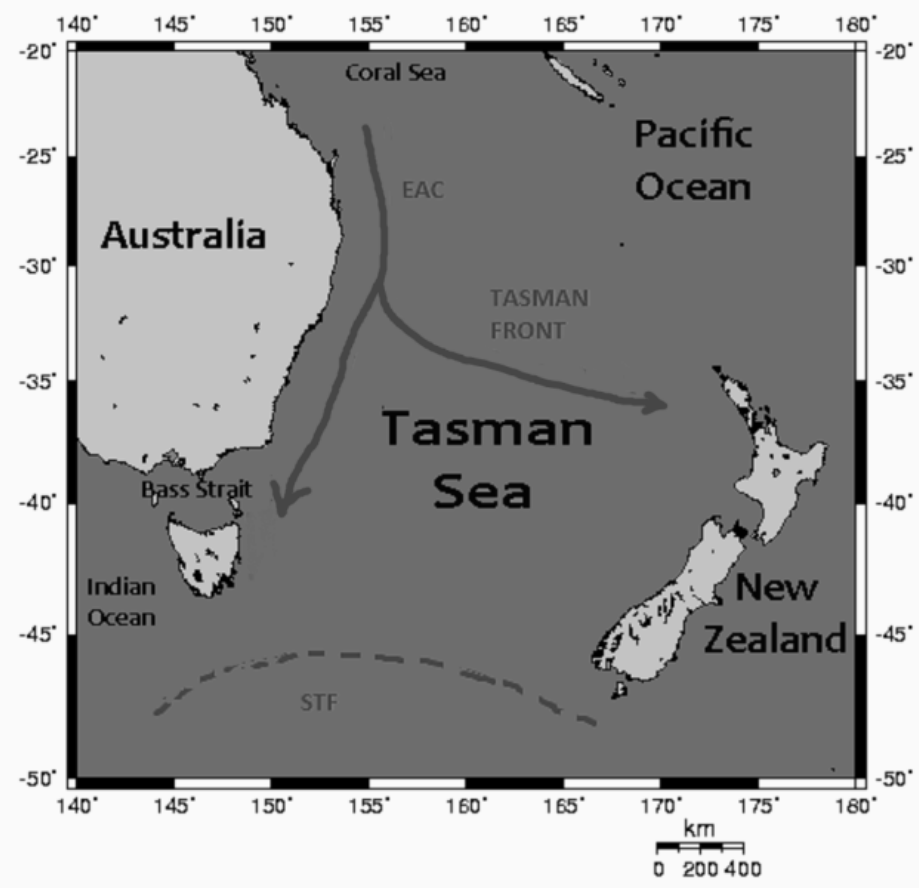

626

627 Fig. 1

628 


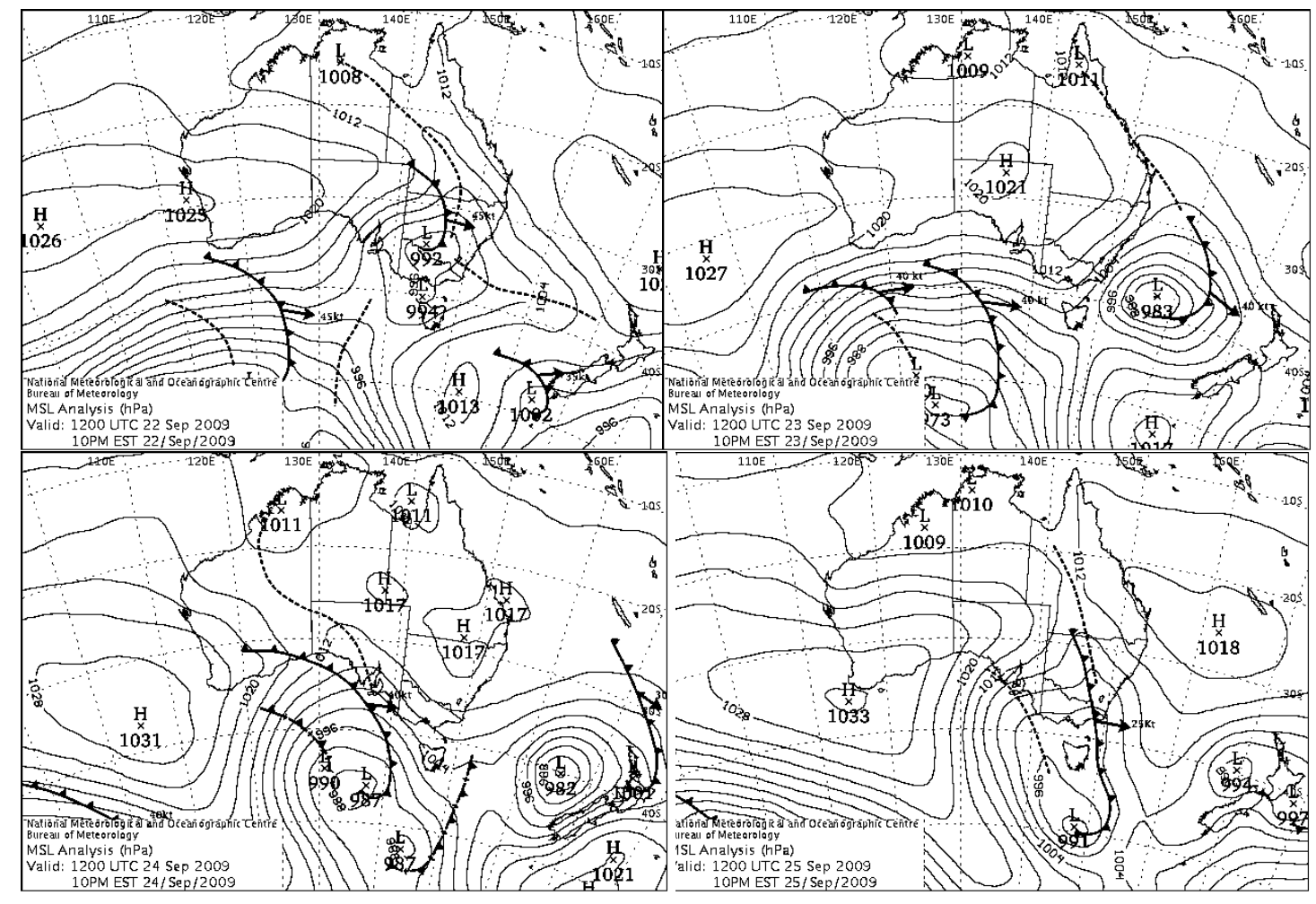

Fig. 2 

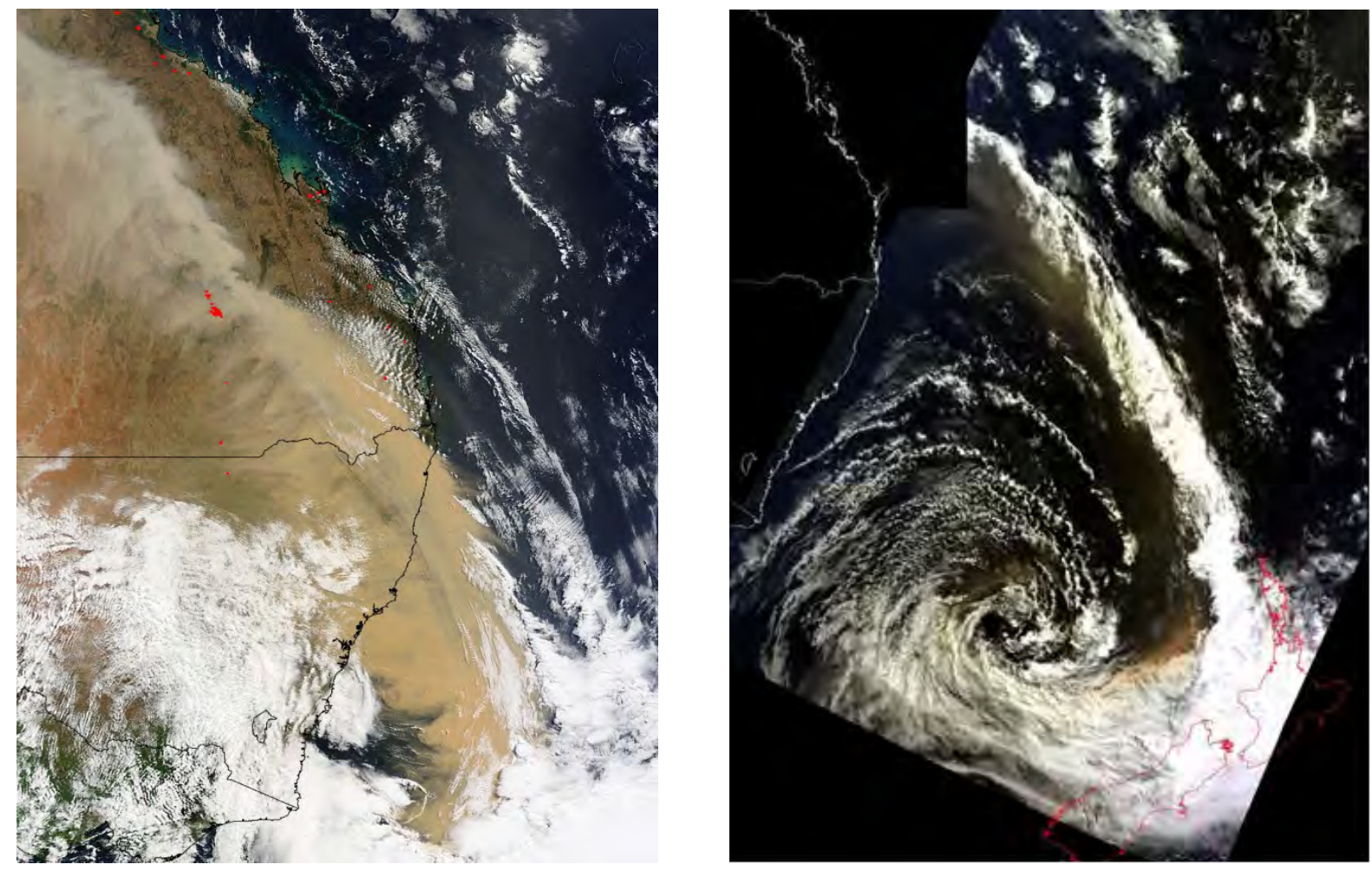

(a)

Fig. 3 


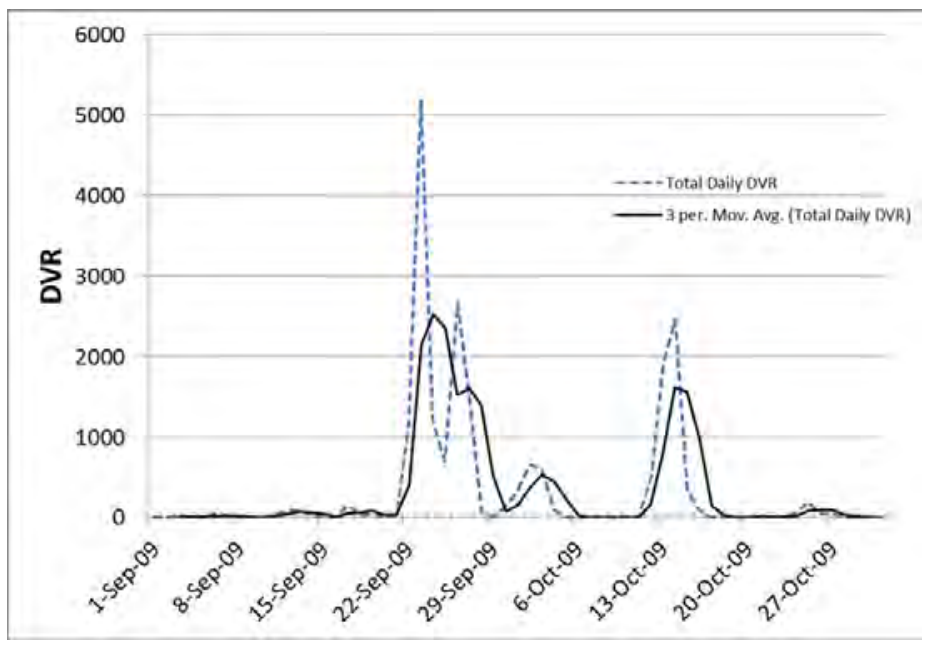

(a)

Area-Averaged Time Series (MYD08 D3.051) (Region: 150E-170E, 40S-25S)

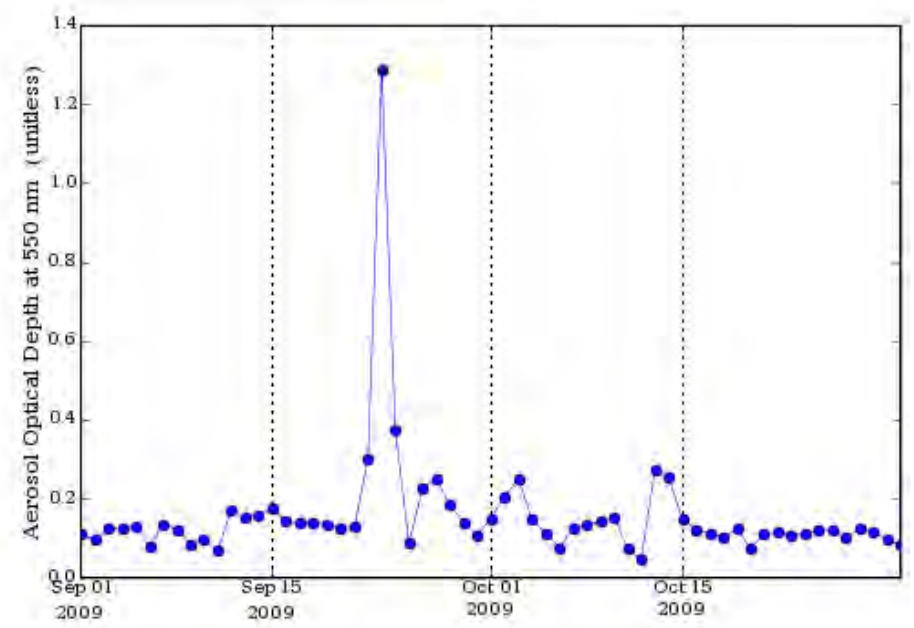

(b) 
MYD08_03.051 Aerosol_optical Depth ak $550 \mathrm{~nm}$ [unitless]

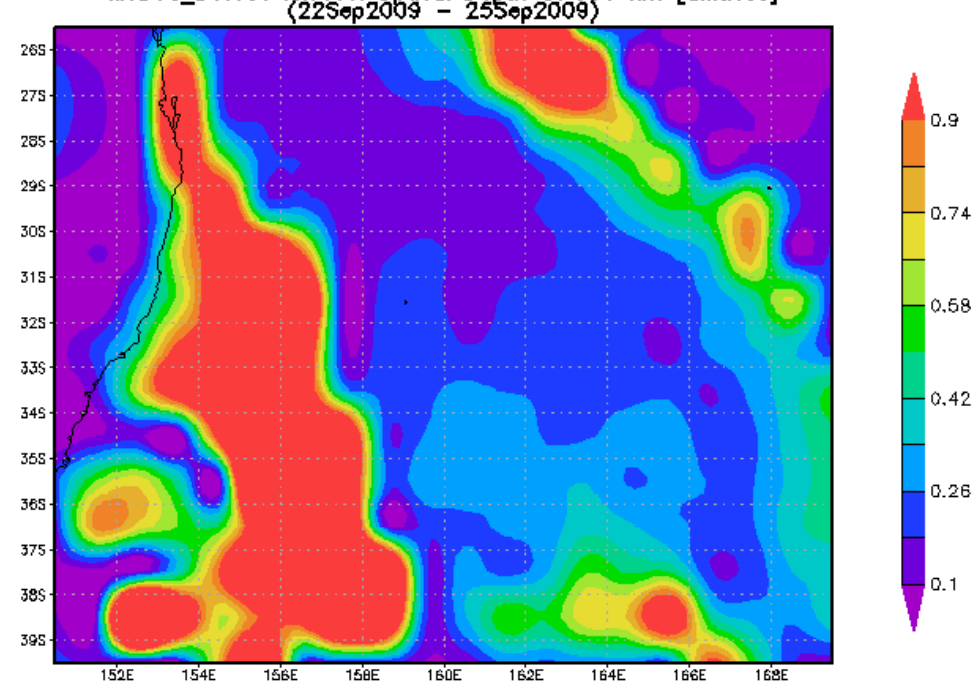

(c)

Fig. 4 


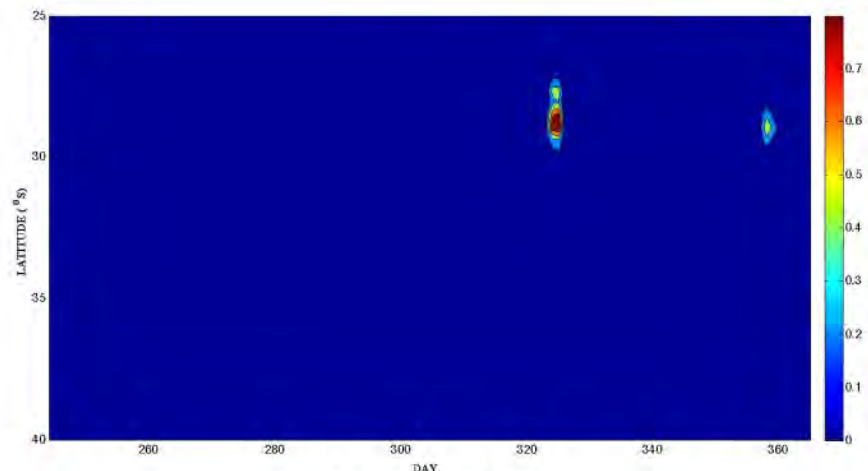

(a) $150-155^{\circ} \mathrm{E}$

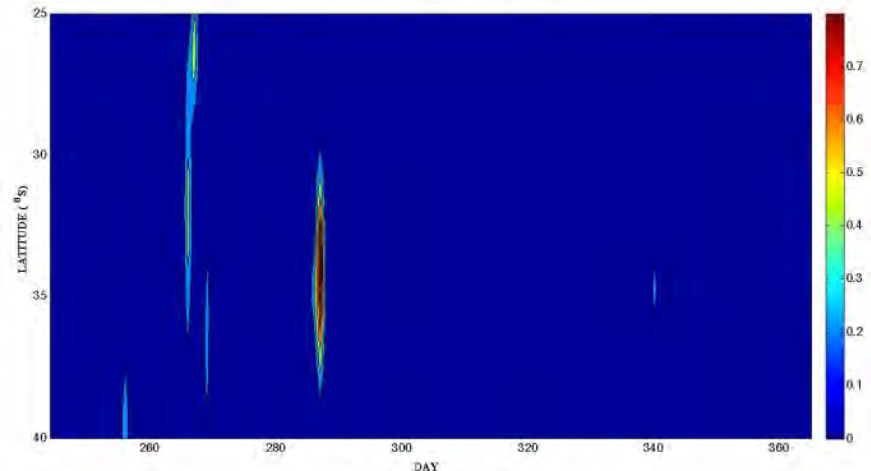

(c) $160-165^{\circ} \mathrm{E}$

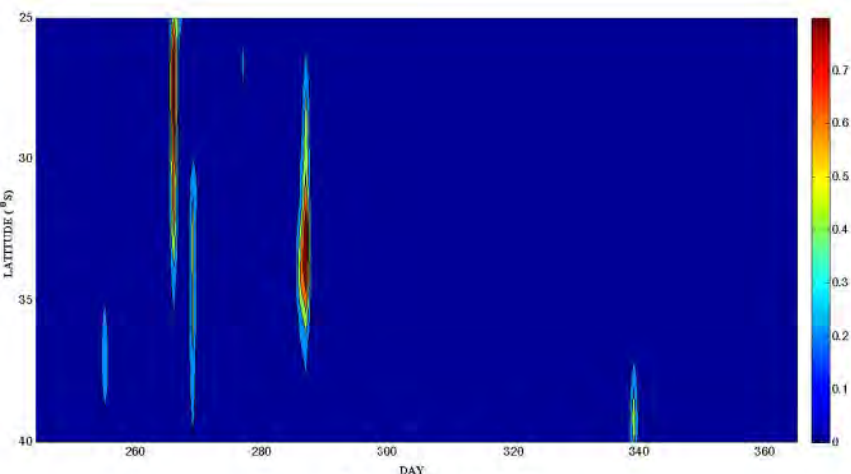

(b) $155-160^{\circ} \mathrm{E}$

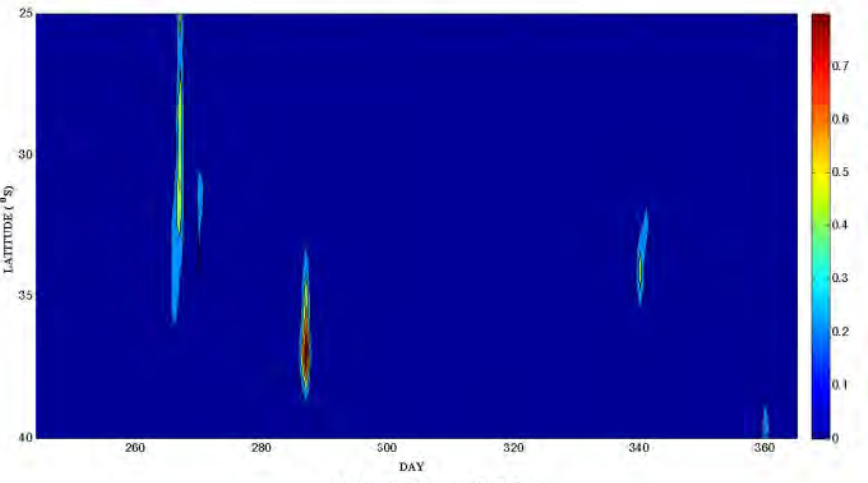

(d) $165-168^{\circ} \mathrm{E}$

Fig. 5 


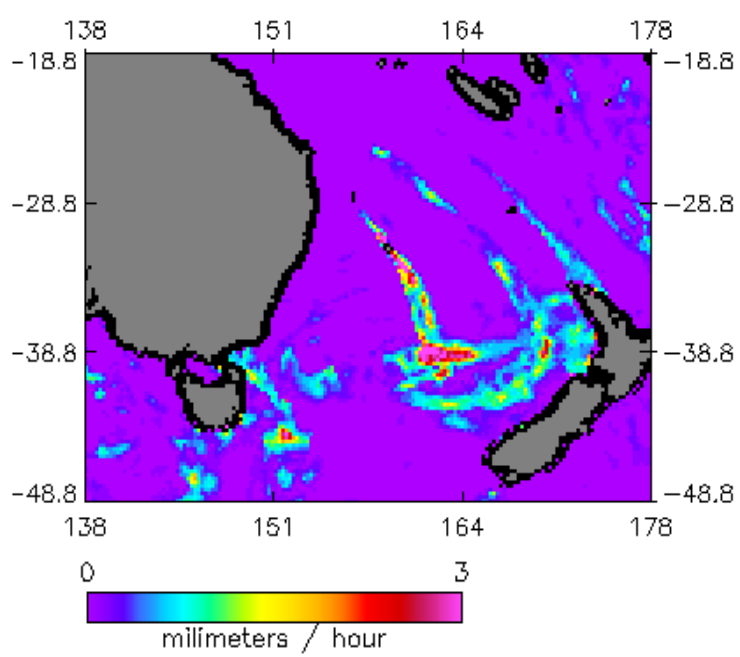

(a)

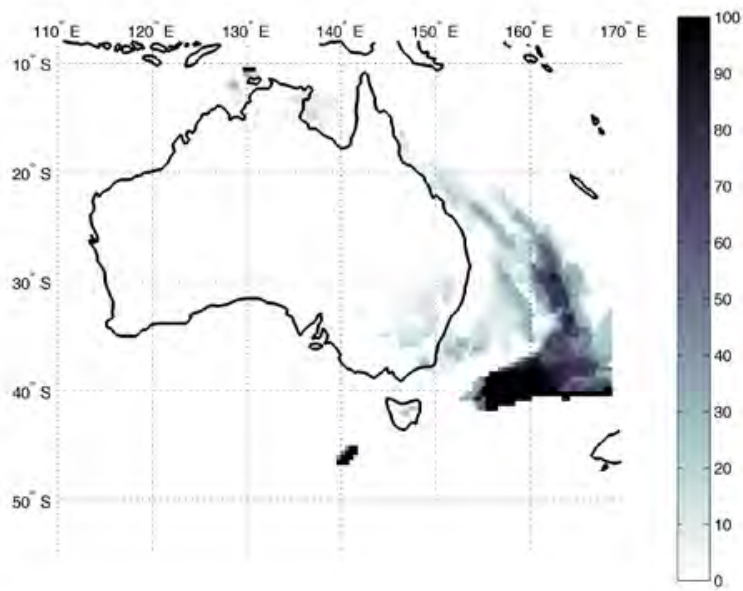

(c)

Fig. 6

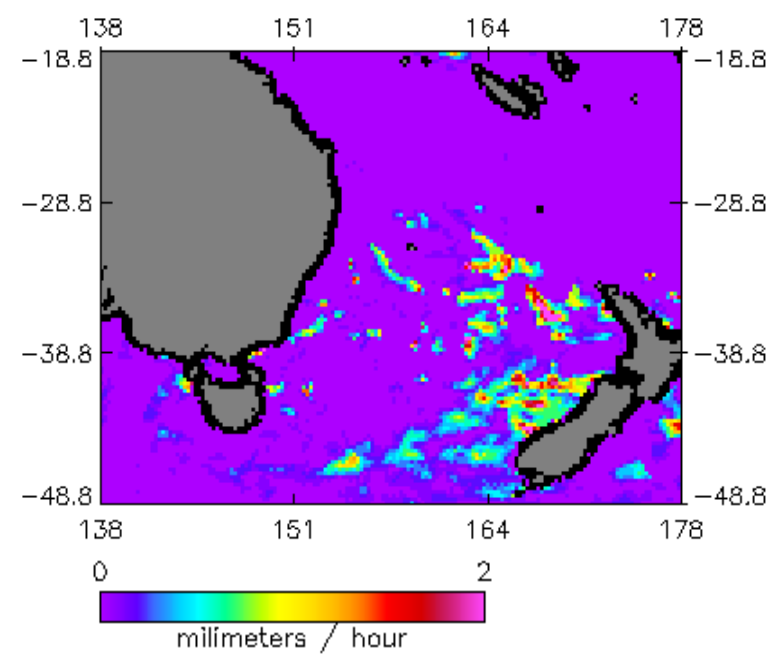

(b)

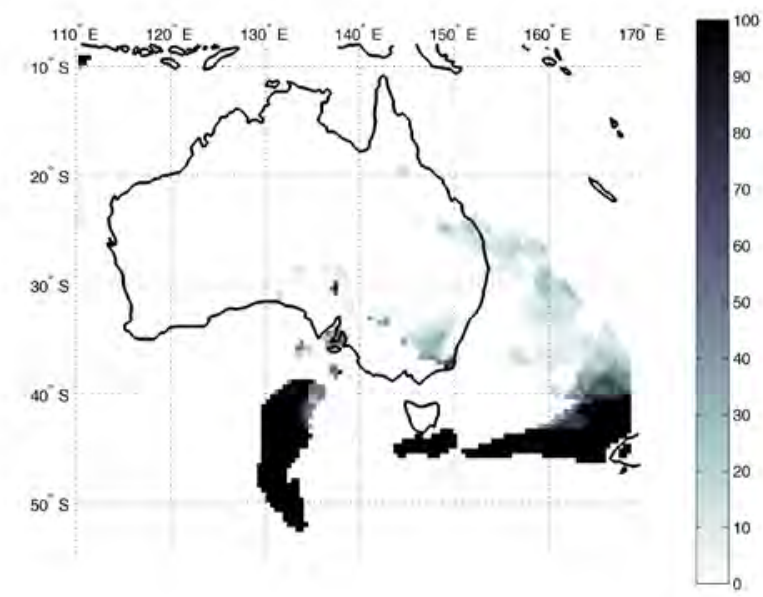

(d) 


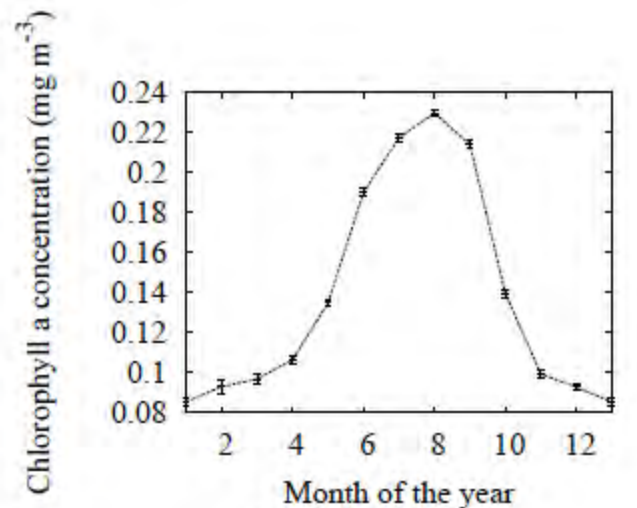

(a) $25-30^{\circ} \mathrm{S}$

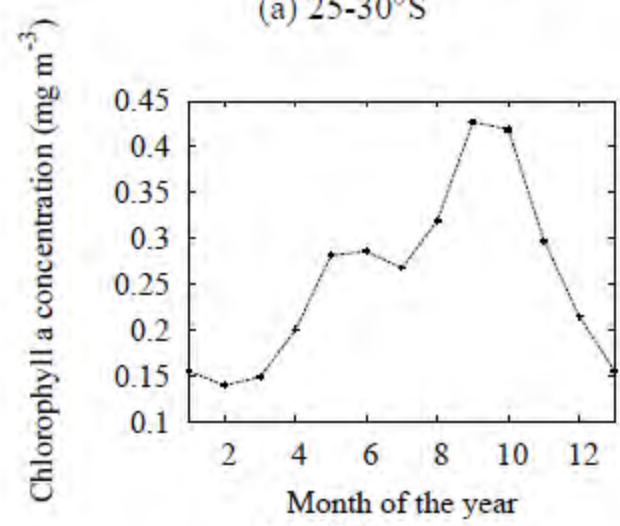

(c) $35-40^{\circ} \mathrm{S}$

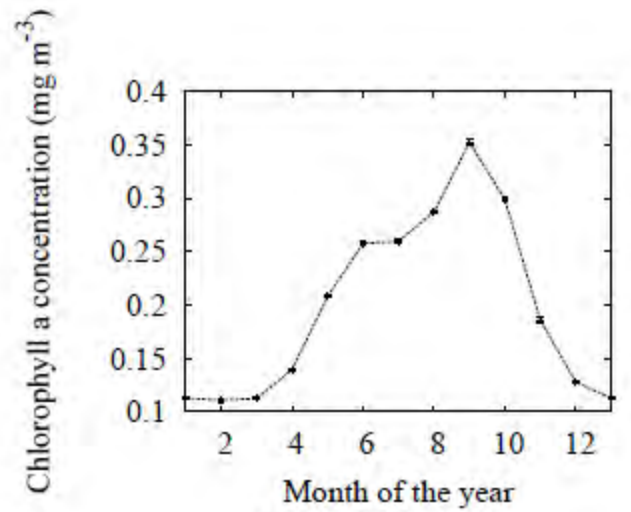

(b) $30-35^{\circ} \mathrm{S}$

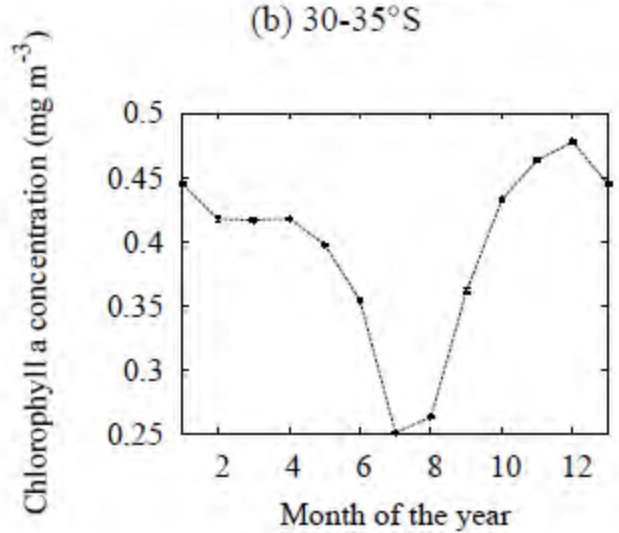

(d) $40-45^{\circ} \mathrm{S}$

Fig. 7 


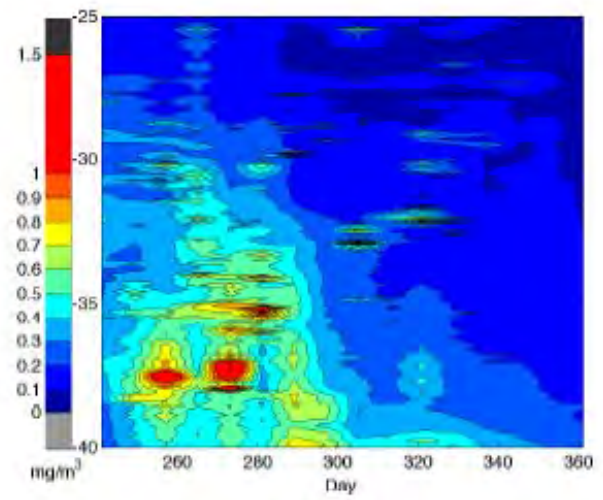

(a) 2009

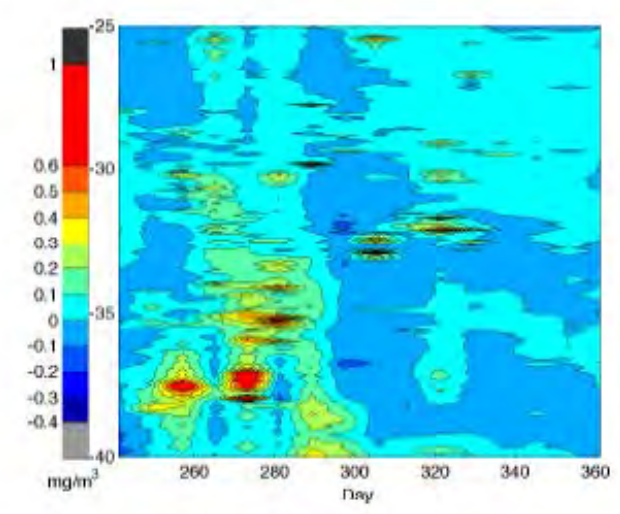

(c) The 2009 anomalies

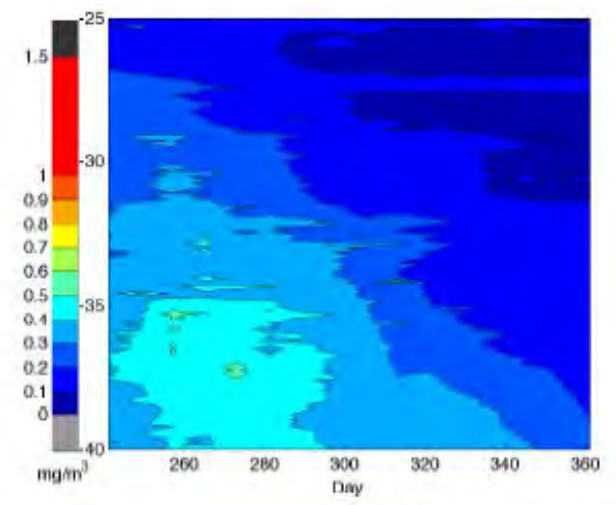

(b) Climatology (2002-2012)

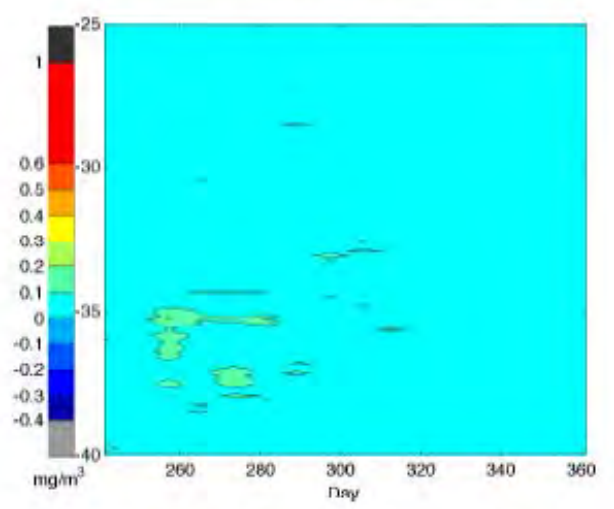

(d) Standard error in climatology

Fig. 8 


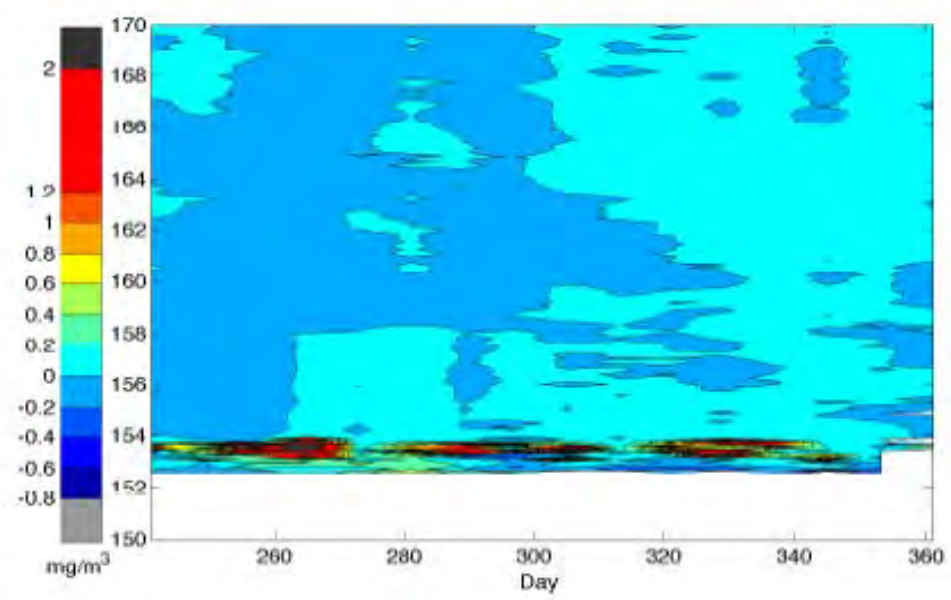

(a) $25-30^{\circ} \mathrm{S}$

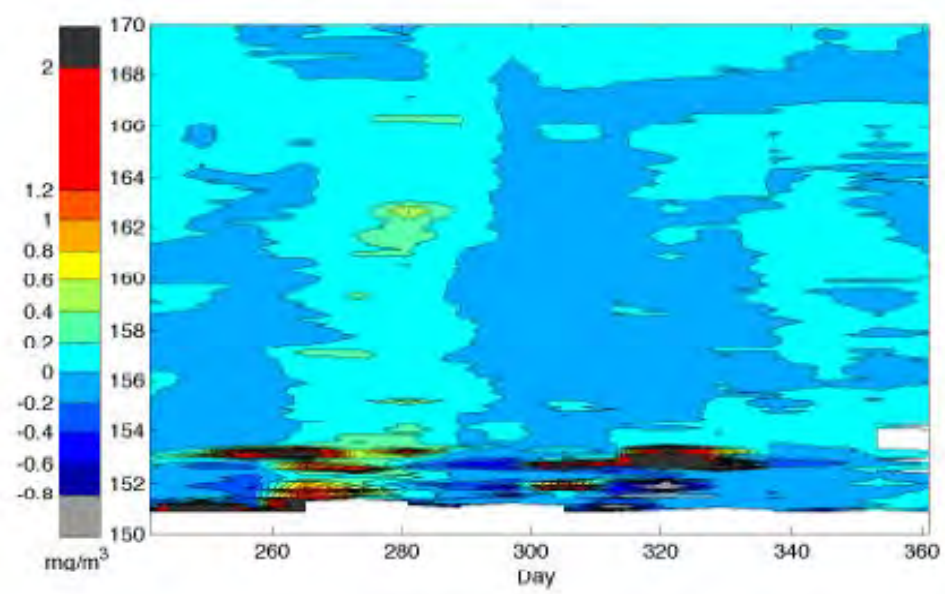

(b) $30-35^{\circ} \mathrm{S}$

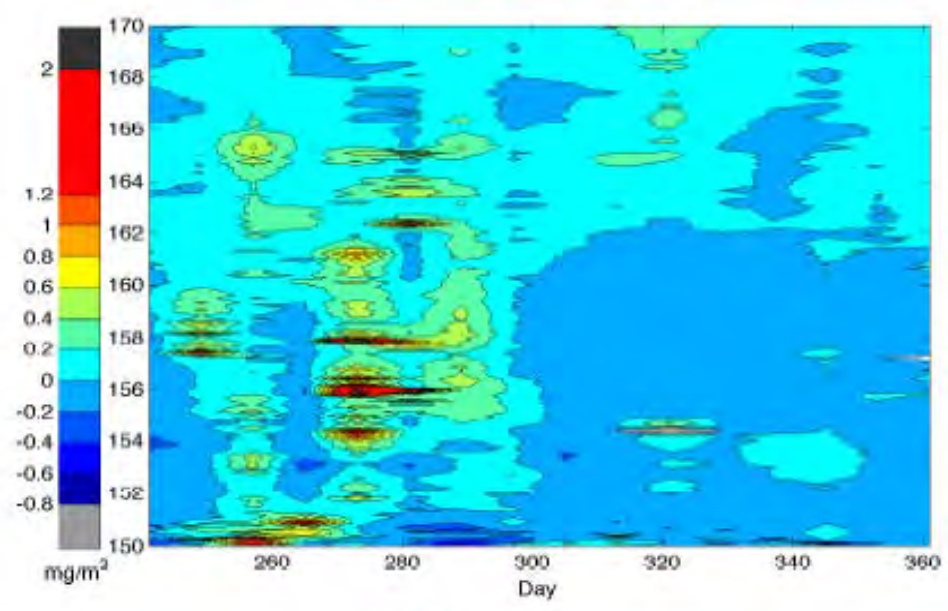

(c) $35-40^{\circ} \mathrm{S}$

Fig. 9 


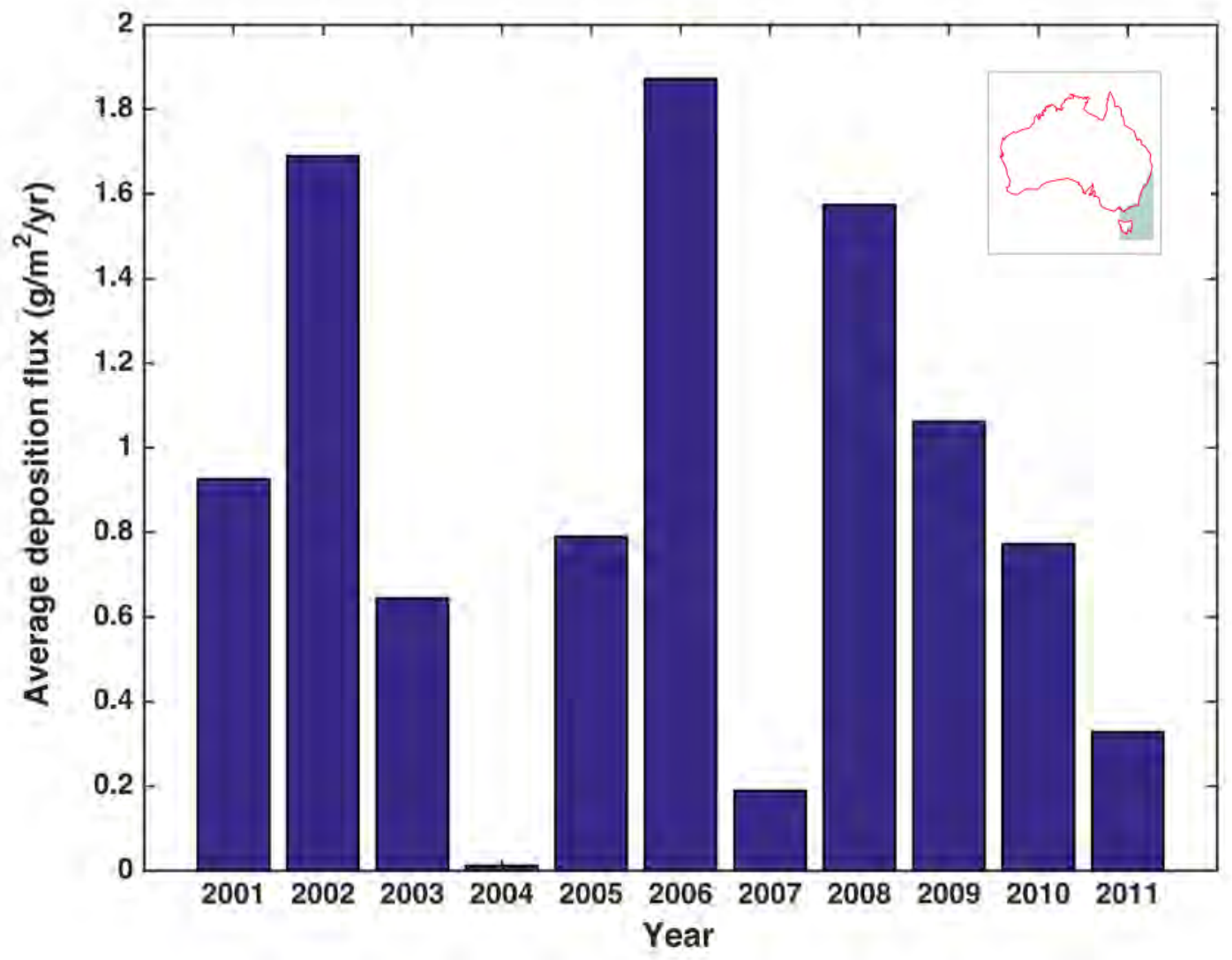

Fig. 10 

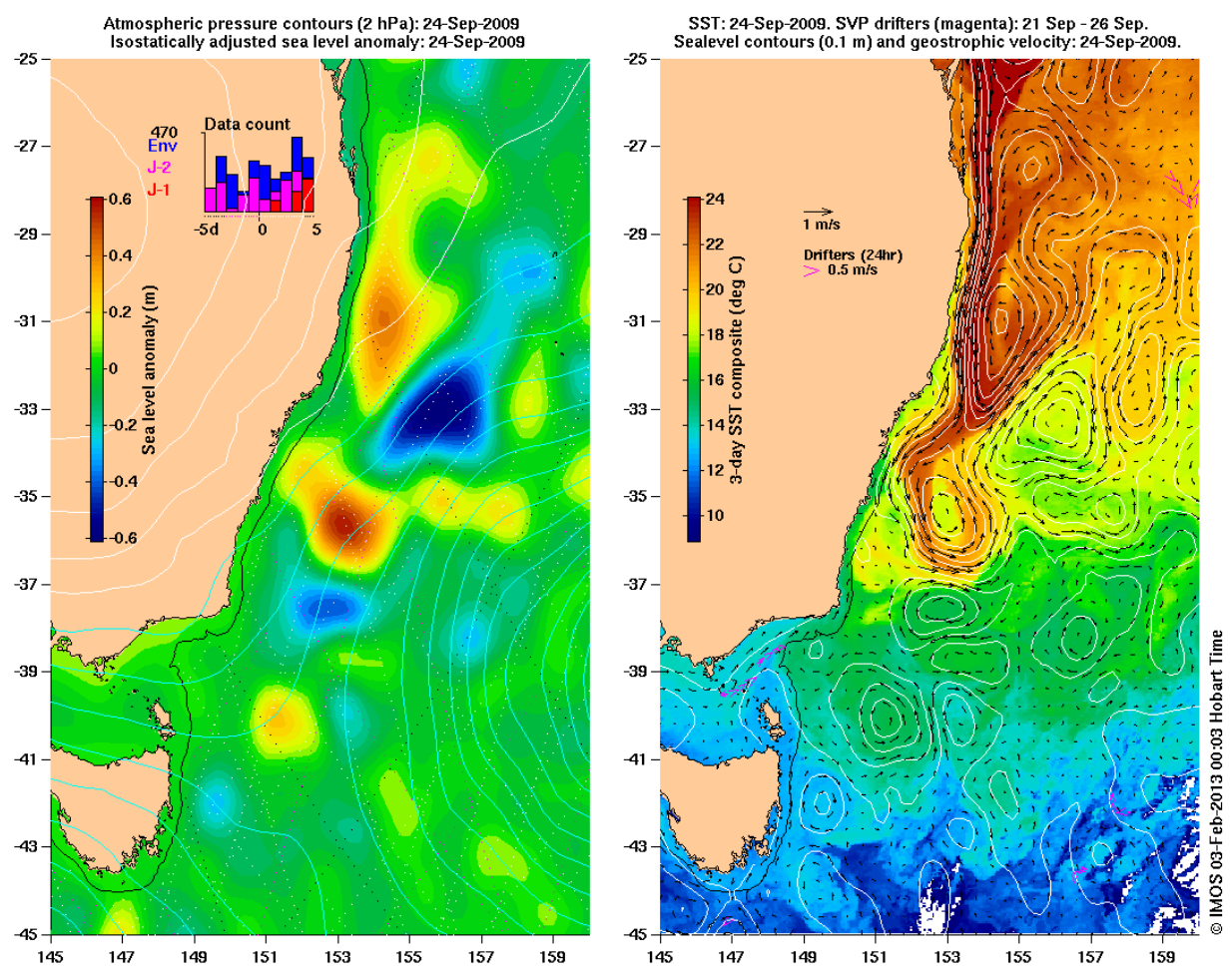

Fig. 11 


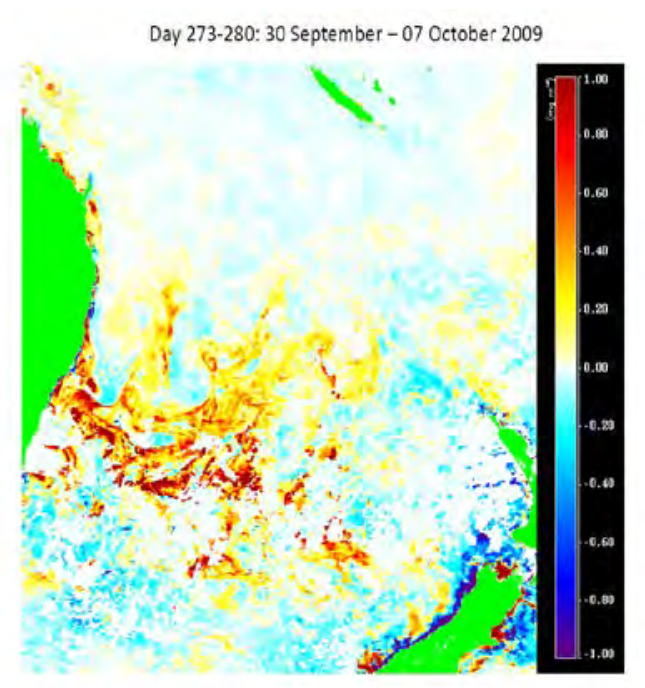

(a)

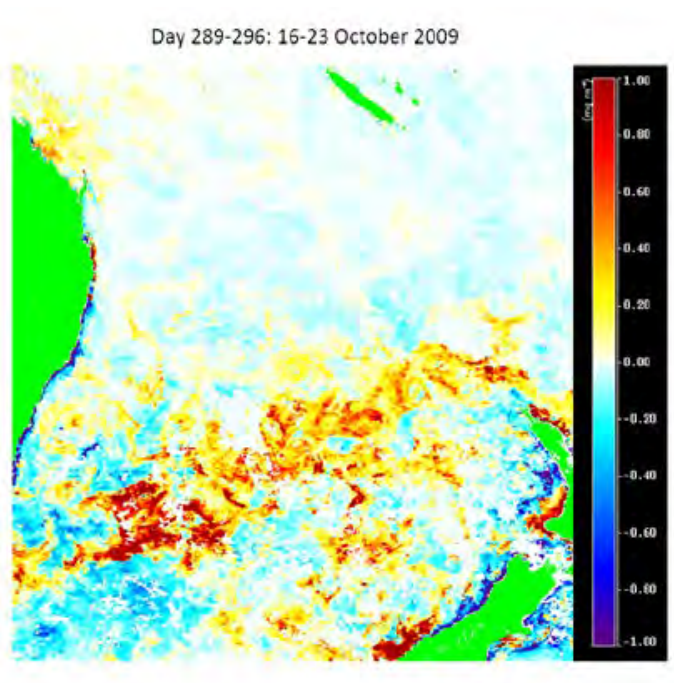

(b)

Fig. 12 